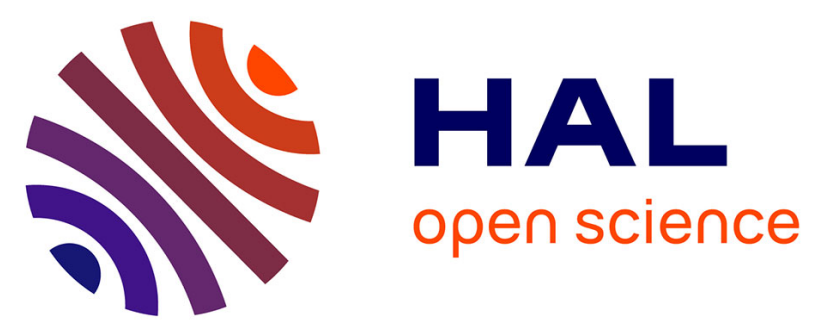

\title{
Cisplatin mediated impairment of mitochondrial DNA metabolism inversely correlates with glutathione levels
}

Nuria Garrido, Acisclo Pérez-Martos, Mercedes Faro, José Manuel

Lou-Bonafonte, Patricio Fernández-Silva, Manuel José López-Pérez, Julio

Montoya, José A Enríquez

\section{To cite this version:}

Nuria Garrido, Acisclo Pérez-Martos, Mercedes Faro, José Manuel Lou-Bonafonte, Patricio FernándezSilva, et al.. Cisplatin mediated impairment of mitochondrial DNA metabolism inversely correlates with glutathione levels. Biochemical Journal, 2008, 414 (1), pp.93-102. 10.1042/BJ20071615 . hal00478928

\section{HAL Id: hal-00478928 \\ https://hal.science/hal-00478928}

Submitted on 30 Apr 2010

HAL is a multi-disciplinary open access archive for the deposit and dissemination of scientific research documents, whether they are published or not. The documents may come from teaching and research institutions in France or abroad, or from public or private research centers.
L'archive ouverte pluridisciplinaire HAL, est destinée au dépôt et à la diffusion de documents scientifiques de niveau recherche, publiés ou non, émanant des établissements d'enseignement et de recherche français ou étrangers, des laboratoires publics ou privés. 


\title{
Cisplatin mediated impairment of mitochondrial DNA metabolism inversely correlates with glutathione levels
}

\author{
Nuria Garrido $^{\text {a,b }}$, Acisclo Pérez-Martos ${ }^{\text {a,b }}$, Mercedes Faro ${ }^{\text {, }, ~}$, José Manuel Lou- \\ Bonafonte $^{c}$, Patricio Fernández-Silva ${ }^{\mathrm{a}, \mathrm{b}}$, Manuel José López-Pérez ${ }^{\mathrm{a}, \mathrm{b}, \mathrm{d}}$, Julio \\ Montoya $^{\text {a,b,d }}$ and José Antonio Enríquez ${ }^{\text {a,b }}$.
}

a) Departamento de Bioquímica y Biología Molecular y Celular, b) Instituto Aragonés de Ciencias de la Salud, c) Departamento de Farmacología y Fisiología, d) Centro de Investigación en Biomedicina en Red de Enfermedades Raras, Universidad de Zaragoza, Miguel Servet 177, Zaragoza 50013, Spain.

Address correspondence to: José Antonio Enríquez, Departamento de Bioquímica y Biología Molecular y Celular, Universidad de Zaragoza, Miguel Servet 177, Zaragoza 50013. Spain. Tel. +34 976761646. Fax: +34 976761612. E-mail: enriquez@unizar.es.

Running Title: Cisplatin and mitochondrial DNA

Key words: cisplatin, mitochondria, mtDNA metabolism, glutathione, anticancer drug toxicity.

\section{SYNOPSIS}

Cisplatin accumulates in mitochondria being this organelle a major target for this drug in cancer cells. Thus, alterations in mitochondrial function have been implicated in cancer cell resistance to chemotherapeutic agents. Moreover, cisplatin toxic side effects seem to be associated with mitochondrial injury in vivo and in vitro. In order to clarify the potential effect of cisplatin in mitochondrial DNA maintenance and expression, we have analyzed rat liver mitochondrial DNA and RNA synthesis as well as their stability under the influence of in vivo treatment or in vitro exposure to cisplatin. We show that cisplatin causes a direct and significant impairment of mtDNA and mtRNA synthesis and decreased steady state levels of mtRNAs in isolated mitochondria. Furthermore, in vivo treatment of the animals with cisplatin exerted a protective effect from the impairment on mitochondrial RNA metabolism caused by in vitro exposure to the drug, by means of increased mitochondrial GSH levels after in vivo cisplatin treatment. 


\section{INTRODUCTION}

Cisplatin is one of the most commonly used chemotherapeutic agents, with demonstrated activity against a diverse spectrum of malignancies including testicular cancer, ovarian carcinoma, and head/neck tumors [1, 2]. However, the therapeutic effectiveness of the drug is limited by the severity of its side effects and the potential progression of tumor cells to a cisplatin-resistant state [3].

In blood, where the chloride concentration is relatively high, cisplatin exists mainly in the dichloro neutral form. Inside the cell, the relatively low chloride concentration favors the replacement of one or both chloride moieties by $\mathrm{H}_{2} \mathrm{O}$, resulting in a positively charged molecule that reacts with nucleophilic sites to crosslink DNA, RNA, and protein [4]. Cisplatin cytotoxicity correlates with DNA adduct formation [5]. Some of the Pt-DNA adducts can be removed by the nucleotide excision repair (NER) mechanism, but others cannot [6]. Pt lesions on DNA impair template function blocking DNA replication, induce a $G_{2}$ cell cycle arrest, inhibit RNA transcription and finally promote cell death through apoptosis [7]. The pathway from cisplatin-induced DNA damage to irreversible apoptotic commitment has not been yet fully defined [8].

Enhanced ability to repair DNA lesions through up-regulation of components of the NER pathway has been proposed to contribute to cisplatin resistance in a number of resistant tumors [9]. Selection for cisplatin resistance in some models has been associated with development of mismatch repair deficiency [10]. Failure to appropriately recognize cisplatin adducts in cells with defects in mismatch repair is hypothesized to lead to replication bypass of lesions, resulting in frequent incorporation of incorrect nucleotides and failure to trigger cell death.

Intracellular cisplatin inactivation by glutathione (GSH) has also been proposed as a mechanism of cisplatin resistance [11]. GSH can either quench DNA-platinum mono-adducts before their conversion to cytotoxic DNA crosslinks [12] or form a complex (or complexes) with cisplatin, thereby reducing the amount of intracellular drug available for interaction with DNA [13].

Although there is evidence that the mechanism of tumor killing involves the formation of DNA crosslinks, the sensitivity of cells to platinum drugs does not always correlate with the formation of DNA adducts [14]. Moreover, the acute side effects of cisplatin are not completely understood indicating that other mechanisms may be involved in the toxicity of the drug.

Mitochondria are subcellular organelles involved in critical metabolic pathways including cellular energy metabolism. Besides the mitochondrial role on cellular ATP production, these organelles are known to be effectors of major apoptotic pathways [15]. A direct inhibition of the respiratory chain rapidly depletes cellular ATP and promotes non-apoptotic (necrotic) cell death [16]. Because of their critical role in cell survival, mitochondria are targets for cellular toxins and chemotherapeutic agents [17].

It has been shown that cisplatin accumulates in mitochondria [18]. The electrochemical gradient resulting in a negative charge within mitochondria may play a role in the accumulation of positively charged cisplatin in this organelle [19]. Indeed, mitochondria are thought to be a major target for cisplatin in cancer cells [20] and alterations in mitochondrial function have been implicated in cancer cell resistance to chemotherapeutic agents [21]. Moreover, cisplatin toxic side effects seem to be associated with mitochondrial injury in vivo and in vitro $[22,23]$. Mitochondria contain their own DNA that is transcribed and translated to synthesize 13 proteins of the mitochondrial electron transport chain [24]. It has been proposed that cisplatin may also 
induce mtDNA damage $[25,26]$. However it remains to be demonstrated if the damage of mtDNA is a primary or a secondary consequence of the cisplatin toxicity.

In this report, we have analyzed the influence of the in vivo treatment and the in vitro addition of cisplatin on mtDNA and mtRNA synthesis and stability. We show that cisplatin caused a direct and significant impairment of the synthesis of mtDNA and the synthesis and steady state of mtRNAs. Furthermore, we provide evidence indicating that GSH levels dramatically influence mitochondrial DNA metabolism. Thus, the in vivo treatment of the animals with cisplatin increases GSH levels, both in cytoplasm and in mitochondrial compartments with a parallel protection of mtDNA metabolism to cisplatin exposure. On the contrary, experimentally induced depletion of mitochondrial GSH impairs mtDNA expression.

These studies provide the basis for the understanding of the effects of cisplatin on mitochondrial activity and the mechanisms of cellular toxicity and resistance caused by this drug.

\section{EXPERIMENTAL PROCEDURES}

Chemicals- Cisplatin, glutathione (GSH), meta-phosphoric acid (MPA), Nethylmaleimide (NEM), sodium borohydride $\left(\mathrm{NaBH}_{4}\right)$, 1-octanol, $N$-ethylmorpholine, monobromobimane $(\mathrm{mBBr})$, acetonitrile (HPLC-grade), ammonium nitrate and ammonium formate were purchased from Sigma Chemical Company. Cisplatin was dissolved in $\mathrm{NaCl} 0.9 \%(1 \mathrm{mg} / \mathrm{ml})$ within 1 hour before use. Concentrated solutions of MPA $(10 \%)$ and NEM $(0.1 \mathrm{M})$ were prepared fresh immediately prior to use. The column and the guard column for high pressure liquid chromatography were obtained from Waters Corporation.

Animals- Wistar rats weighing 200 to 250 gr. were fed laboratory chow and water ad libitum and used for the experiments. In cisplatin in vivo studies, groups of 3 rats were injected intraperitoneally (i.p.) with a simple dose of cisplatin: 10 or $20 \mathrm{mg} / \mathrm{kg}$ of body weight. The animals were killed by decapitation 5,24 or 48 hours after the administration. Controls were injected with saline alone, and one control animal was killed with each one of the experimental groups.

Isolation of rat liver mitochondria- The liver was rapidly removed chilled in homogenization medium and mitochondrial fractions were purified as described elsewhere [27]. The final mitochondrial pellet was resuspended in the corresponding buffer for DNA or RNA synthesis or for GSH determination.

Sample preparation for GSH determination- The sample preparation for GSH analysis was performed according to Rebrink et al. [28] with little modification. Total GSH determination was carried out on crude homogenates just after homogenization of the liver as mentioned above. $200 \mu \mathrm{l}$ aliquots of the crude homogenates were mixed with $200 \mu \mathrm{l}$ of ice-cold $10 \%$ (w/v) meta-phosphoric acid (MPA) for deproteinization. After $30 \mathrm{~min}$ of incubation on ice, samples were centrifuged at $14000 \mathrm{~g}$ for $20 \mathrm{~min}$ at $4^{\circ} \mathrm{C}$. Supernatants were used immediately for $\mathrm{GSH}$ determination or stored at $-80^{\circ} \mathrm{C}$ for up to 4 months.

For measurement of mitochondrial GSH content, $200 \mu \mathrm{l}$ aliquots of fresh mitochondrial preparations containing $2 \mathrm{mg}$ protein $/ \mathrm{ml}$ were washed once with a 10fold excess of buffer and pelleted by centrifugation. The mitochondrial pellets were suspended in $200 \mu \mathrm{l}$ of $5 \%(\mathrm{w} / \mathrm{v}) \mathrm{MPA}$, incubated $30 \mathrm{~min}$ on ice and centrifuged at $18000 \mathrm{~g}$ for $20 \mathrm{~min}$ at $4^{\circ} \mathrm{C}$. Supernatants were used immediately for GSH determination or stored at $-80^{\circ} \mathrm{C}$ until analysis.

Protein concentration in homogenates and mitochondrial fractions was determined by the Bradford method [29]. 
Derivatization of GSH and quantitation by HPLC- Derivatization procedure was performed essentially as described by Pastore et al. [30]. Briefly, $10 \mu \mathrm{l}$ of $4 \mathrm{M} \mathrm{NaBH}_{4}$ (dissolved in $333 \mu \mathrm{l} / \mathrm{ml}$ dimethyl sulfoxide and $66 \mathrm{mM} \mathrm{NaOH}$ ), $5 \mu \mathrm{l}$ of a solution containing $2 \mathrm{mM}$ EDTA and $2 \mathrm{mM}$ DTT, $5 \mu \mathrm{l}$ of 1 -octanol, and $5 \mu \mathrm{l}$ of $2 \mathrm{M} \mathrm{HCl}$ were mixed and spun down in a derivatization vial. $10 \mu \mathrm{l}$ of homogenate or mitochondrial supernatant (in 5\% w/v MPA) was added, mixed, and spun down. After $1 \mathrm{~min}$ incubation, $25 \mu \mathrm{l}$ of $N$-ethylmorpholine buffer ( $2 \mathrm{M} \mathrm{N}$-ethylmorpholine, $\mathrm{pH} 8.0$ ) and 10 $\mu \mathrm{l}$ of $25 \mathrm{mM}$ bromobimane (in 1:1 acetonitrile: $\mathrm{H}_{2} \mathrm{O}$ by volume) were added to the derivatization vial. After 1 min of incubation the reaction was stopped with $4.2 \mu \mathrm{l}$ of glacial acetic acid. All operations were carried out at room temperature.

GSH was analyzed with a Waters HPLC system, equipped with two 515 HPLC pumps. $10 \mu \mathrm{l}$ of derivatized sample were injected using a Waters 717 autosampler into a $150 \times 3.9 \mathrm{~mm}$ Nova-Pack C-18 column ( $4 \mu \mathrm{m}$ particle size), equilibrated with $5 \%$ buffer A (acetonitrile)-95\% buffer B (30 mM ammonium nitrate and $40 \mathrm{mM}$ ammonium formate buffer, $\mathrm{pH}$ 3.6). Samples were eluted from the column with a 20 min gradient of buffer A (0-7.50 min, 5\% buffer A-95\% buffer B; 7.50-10.50 min, 100\% buffer A; $10.50-16.00 \mathrm{~min}, 100 \%$ buffer A; $16.00-18.00 \mathrm{~min}, 5 \%$ buffer A-95\% buffer B; 18.00 $20.00 \mathrm{~min}, 5 \%$ buffer $\mathrm{A}-95 \%$ buffer $\mathrm{B}$ ) at a flow rate of $1.5 \mathrm{ml} / \mathrm{min}$. The column was run at $33^{\circ} \mathrm{C}$. Under these conditions, sample analysis was completed in 20 min and GSH was the only thiol eluting peak with a retention time of $7.90 \mathrm{~min}$. Calibration standards for GSH were prepared in duplicate by diluting of $2 \mathrm{mM}$ stock solution of GSH in 5\% (w/v) MPA. For the detection of derivatized GSH a Waters 474 scanning fluorescence detector operating at an excitation wavelength of $390 \mathrm{~nm}$ and an emission wavelength of $478 \mathrm{~nm}$ was used. The Empower Login program for Windows 2000 (Waters) was used for controlling HPLC system and analyzing GSH results. Each sample was injected twice and the average of peak areas was used for calculations of the GSH concentrations.

Synthesis of DNA and RNA in isolated rat liver mitochondria- Mitochondrial DNA and RNA synthesis assays were performed as described elsewhere [27]. Briefly, reactions were performed in $0.5 \mathrm{ml}$ at mitochondrial concentration of $2 \mathrm{mg} / \mathrm{ml}$ in both cases. For DNA synthesis, $50 \mathrm{mM}$ dATP, dGTP, dCTP and $20 \mu \mathrm{C}\left[\alpha_{-}{ }^{32} \mathrm{P}\right] \mathrm{dTTP}(2000 \mu \mathrm{C} / \mathrm{mmol})$ were added to the incubation tube and incubation was carried out at $37^{\circ} \mathrm{C}$ for 3 hours on a rotating wheel [27].

For RNA synthesis, $20 \mu \mathrm{C}\left[\alpha-{ }^{32} \mathrm{P}\right] \mathrm{UTP}(800 \mu \mathrm{C} / \mathrm{mmol})$ was added to the medium. The incubation was maintained at $37^{\circ} \mathrm{C}$ for $60 \mathrm{~min}$ on a rotary shaker $(12 \mathrm{rpm})$ [31].

After DNA or RNA synthesis mitochondria were centrifuged at $14000 \mathrm{~g}$ for 1 min and washed twice with $0.5 \mathrm{ml}$ of $10 \%$ glycerol, $0.15 \mathrm{mM} \mathrm{MgCl}_{2}, 10 \mathrm{mM}$ Tris-HCl, $\mathrm{pH} 6.8$.

Mitochondrial nucleic acids extraction- Mitochondrial lysis and nucleic acid extraction were carried out as described before [27]. Briefly, the mitochondrial pellet was resuspended in $500 \mu \mathrm{l}$ of pronase buffer $(10 \mathrm{mM}$ Tris- $\mathrm{HCl}, \mathrm{pH} 7.4,150 \mathrm{mM} \mathrm{NaCl}, 1$ $\mathrm{mM}$ EDTA-Na), lysed with $2 \%$ SDS in the presence of $100 \mu \mathrm{g}$ the pronase (autodigested to remove nucleases) and incubated for $15 \mathrm{~min}$ at $37^{\circ} \mathrm{C}$. Total mitochondrial nucleic acids were extracted twice with an equal volume of a phenol/chloroform/isoamylic alcohol mixture (25:25:1) at room temperature. After ethanol precipitation and centrifugation, the pelleted nucleic acids were dissolved in 10 $\mathrm{mM}$ Tris-HCl, $\mathrm{pH}$ 7.4, 1 mM EDTA. 
Mitochondrial DNA was analyzed directly or after digestion with DNase RNase free and the restriction enzyme BamHI by vertical 1\% agarose slab gel electrophoresis [27]. Mitochondrial RNAs were analyzed by methylmercury hydroxide-agarose gels as previously described [32].

After the run, the gels were first stained with ethidium bromide, photographed under UV light, dried and exposed for autoradiography either at $-70^{\circ} \mathrm{C}$ with a DuPont screen intensifier or at room temperature as needed.

The amount of total mitochondrial DNA or RNA was quantified by densitometry of the gel bands after electrophoresis, stain with ethidium bromide and photography of the gel with an LKB Ultroscan XL laser densitometer and Gel Scan XL software.

The Amount of DNA or RNA synthesized by isolated mitochondria was quantified by densitometry of the autoradiograms with an LKB Ultroscan XL laser densitometer and Gel Scan XL software. Images were acquired with an Epson Perfection 1250 scanner and Adobe Photoshop CS 8.0.1 software.

$\mathrm{O}_{2}$ consumption- Mitochondrial $\mathrm{O}_{2}$ consumption was measured polarographically at $37^{\circ} \mathrm{C}$ in a closed $1.0 \mathrm{ml}$ reaction chamber fitted with a Clark $\mathrm{O}_{2}$ electrode (Yellow Springs Instrument, Yellow Springs $\mathrm{OH}$ ). One milligram of mitochondrial protein was added to $0.9 \mathrm{ml}$ incubation medium to initiate the study of mitochondrial respiration. The incubation medium was composed of $25 \mathrm{mM}$ sucrose, $75 \mathrm{mM}$ sorbitol, $100 \mathrm{mM}$

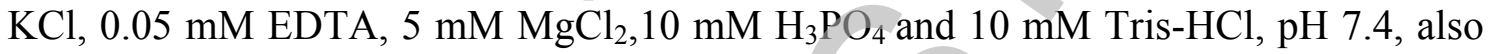
containing $1 \mathrm{mg} / \mathrm{ml}$ fatty acid-free bovine serum albumin (BSA). Respiration started with the addition of Complex I substrates $10 \mathrm{mM}$ glutamate and $2.5 \mathrm{mM}$ malate. After 1-3 $\mathrm{min}, 0.2 \mathrm{mM}$ ADP was added to initiate state 3 respiration. After ADP was fully converted to ATP, state 4 respiration was measured. $0.2 \mu \mathrm{M} \mathrm{KCN}$ was added to inhibit Complex I activity. Mitochondrial respiration rates (state 3 and state 4) were expressed as nanoatom $\mathrm{O}_{2} \cdot \mathrm{min}^{-1} \cdot \mathrm{mg}$ mitochondrial protein ${ }^{-1}$ or nanoatom $\mathrm{O}_{2} \cdot \mathrm{min}^{-1} \cdot \mathrm{mtDNA}^{-1}$ (a.u.). The respiratory control ratio (RCR) is indicative of mitochondrial coupling, and was expressed as the state 3 / state 4 ratio.

The $\mathrm{P} / \mathrm{O}$ ratio (moles of synthesized ATP per atom of oxygen transformed to water during oxidative phosphorilation) was also calculated as a measurement of mitochondrial coupling.

PCR amplification of $m t D N A$ - Mitochondria and mitochondrial DNA were isolated as described before and incubated with and without cisplatin as described in the figures. The oligonucleotide primers used in this study, as indicated below, were prepared by Gibco BRL. Various segments of mtDNA were amplified using the following oligonucleotides:

H-OH-5' -CCTGTGGAACCTTTTAGTTAAG-3'

L-OH-5'-TTTGGCATTGAAGTTTCAGGTG-3'

H-IL-5'-CCCCAAAAACATTAAAGCAAGA-3'

L-IL-5'-GAATCCATCTAAGCATTTTCAG-3'

H-ND-5'-GATTAGTGTTAGGATATTA-3'

L-16S-5'-CCCAGTTACGAAAGGACAAGAG-3'

L-Cys-5' -CCCAAGTTATTAGGGTGGCA-3'

H-Cys-5'-GCGTATTCGACGTTAAAGCC-3'

All amplification reactions were carried out in $0.2 \mathrm{ml}$ PCR tubes in a final volume of $50 \mu \mathrm{l}$. Each reaction consisted on $0.5 \mu \mathrm{g}$ of mtDNA, $2.5 \mu \mathrm{M}$ of each primer, $200 \mu \mathrm{M}$ dNTP, $2 \mathrm{mM} \mathrm{MgCl}$, 2.5 units Taq DNA polymerase (Epicenter Technologies, Madison, WI), and the supplied reaction buffer. For the amplification of mtDNA, 
samples underwent an initial denaturation at $94^{\circ} \mathrm{C}$ for $10 \mathrm{~min}$, followed by 40 cycles of template denaturation at $94^{\circ} \mathrm{C}$ for $1.30 \mathrm{~min}$, primer-template annealing at $55^{\circ} \mathrm{C}$ for 1.30 min and primer extension at $72^{\circ} \mathrm{C}$ for $1.30 \mathrm{~min}$. At the end of the 30 cycles, extension was allowed to continue for an additional $7 \mathrm{~min}$. PCR amplification was performed on a programmable thermal cycler (Biometra, Trio Termocycler). The amplified products were separated on horizontal $1 \%$ agarose gel electrophoresis with $1 \%$ ethidium bromide. After the run, the gels were photographed under UV light. Amounts of amplified DNA were quantified by densitometry with an LKB Ultroscan XL laser densitometer and Gel Scan XL software.

Statistical analysis- Results were shown as the mean plus the standard deviation. The statistical analysis was carried out by Mann Whitney test. $\mathrm{p}<0.05$ was considered statistically significant.

\section{RESULTS}

\section{Cisplatin impairs mitochondrial respiration.}

Mitochondria isolated from rat liver were incubated at $37^{\circ} \mathrm{C}$ in the absence or in the presence of different cisplatin concentrations for 1,2 or 3 hours and subjected to oxygen consumption measurement. State 3 and state 4 respiration were measured and the respiratory control ratio (RCR) and the $\mathrm{P} / \mathrm{O}$ ratio were calculated (Fig. 1A). Cisplatin caused a dose and time dependent decrease in the RCR (Fig. 1A, upper panel) and the $\mathrm{P} / \mathrm{O}$ ratio was less sensitive to cisplatin, but it also showed a dose and time dependent increase (Fig. 1A, lower panel) indicating an impairment of the OXPHOS system function.

\section{Cisplatin inhibits mitochondrial DNA synthesis.}

Since cisplatin can form adducts with DNA, we investigated if mitochondrial DNA was functionally affected by the presence of the drug. To evaluate this possibility, the direct effect of cisplatin on mitochondrial DNA replication in isolated organelles was evaluated. Rat liver mitochondria were incubated for 3 hours at $37^{\circ} \mathrm{C}$ with $\left[\alpha-{ }^{32} \mathrm{P}\right]$ TTP in the presence of cisplatin concentrations varying from 0 to $0.7 \mathrm{mM}$. After incubation, mitochondrial nucleic acids were isolated and examined by electrophoresis. As shown in Fig. 1B, cisplatin significantly inhibited mtDNA replication in organello. The inhibition was dose-dependent with a range of cisplatin concentrations between 0 and $0.7 \mathrm{mM}$. At concentrations higher than $0.2 \mathrm{mM}$, cisplatin inhibited mtDNA synthesis within 1 hour. The inhibition affected all the different mtDNA conformations [27]. Cisplatin did not have any effect on radioisotope capture by the isolated mitochondria (TTP uptake, Fig. 1B).

Inhibition of mtDNA replication could be either due to impairment of the OXPHOS capacity induced by cisplatin or to a direct modification of the mtDNA template, as it has been postulated for nuclear DNA. In order to evaluate which one of the two mechanisms is determining the observed effect, we used a PCR-based assay [33] in which many DNA lesions would block the Taq DNA polymerase progression and result thereby in a specific decrease in amplification of the damaged DNA template. Mitochondria isolated from rat liver were incubated for 1 hour at $37^{\circ} \mathrm{C}$ in the presence of varying concentrations of cisplatin ( 0 to $1.4 \mathrm{mM}$ ). After the incubation, nucleic acids were extracted and used as template for PCR amplification. Also, $1.4 \mathrm{mM}$ cisplatin was added to one of the DNA control samples just before the PCR amplification. PCR products were then analyzed on agarose gels. As shown in Fig. 1C, left panel, the amount of amplified mtDNA decreased in a dose-dependent manner after incubation 
with cisplatin, while it was not affected by the presence of cisplatin exclusively during the PCR amplification reaction $\left(\mathrm{C}_{1}\right)$. Various mtDNA regions were affected by cisplatin at different extent, a fact that could be explained by the length of the amplification fragment (Fig. 1C, right panel). The region amplified by H-Cys/L-Cys (1), the largest one, showed the higher synthesis inhibition, whereas $\mathrm{H}-\mathrm{OH} / \mathrm{L}-\mathrm{OH}$ (4), the shorter one, showed the less amplification inhibition.

These results indicated that cisplatin produced a direct and non-specific structural alteration on mtDNA, which caused an inhibition of mtDNA amplification by PCR and, very likely, contributed to the inhibition of mitochondrial DNA synthesis in organello.

\section{Cisplatin inhibits mitochondrial DNA transcription.}

The next question to be answered was whether cisplatin also interfered with mtDNA transcription. Again, mitochondria isolated from rat liver were incubated for 1 hour at $37^{\circ} \mathrm{C}$ with $\left[\alpha-{ }^{32} \mathrm{P}\right]$ UTP in the presence of cisplatin concentrations varying from 0 to $1.4 \mathrm{mM}$. After incubation, mitochondrial nucleic acids were isolated and examined by electrophoresis.

Analogous to the effect on replication, cisplatin caused a dramatic inhibition of mtDNA transcription in organello (Fig. 2A). The inhibition was already detectable at concentrations as low as $0.17 \mathrm{mM}$ and was complete at $0.7 \mathrm{mM}$. The densitometric analysis of the RNA electrophoretic patterns normalized by the mtDNA amount loaded in each lane, showed that the inhibition affected to all mtRNA species: ribosomal and messenger RNAs. Cisplatin did not have any effect on radioisotope capture by the isolated mitochondria (UTP uptake, Fig. 2A, left panel). In addition, the effect of 0.17 $\mathrm{mM}$ cisplatin was time-dependent, observing increased inhibition from 1 to 3 hours (Fig. 2A, right panel).

\section{Cisplatin decreases mitochondrial RNA stability.}

Incubation of the organelles in the presence of cisplatin did not affect mtDNA steady state (Fig. 2B, upper band), but the levels of the in vivo mtRNAs were decreased in a dose and time-dependent manner (Fig. 2B, lower bands) as determined from the stained gels (see Material and Methods). We observed a general decrease in the amount of the mtRNAs that was particularly evident for the $12 \mathrm{~S}$ and $16 \mathrm{~S}$ ribosomal RNAs. Thus, we determined whether a decrease in mitochondrial RNA stability (Fig. 2B) caused by cisplatin could explain the reduction on the amount of newly synthesized RNA in isolated mitochondria (Fig. 2A). Comparison of the effect of cisplatin on mtRNA stability with the effect on RNA synthesis revealed that the decreased RNA levels could not be explained only because of the reduction of the stability (not shown).

The results described above demonstrated that cisplatin causes a direct damage of mitochondrial biogenesis by inhibiting mitochondrial DNA synthesis and transcription and by destabilizing the mitochondrial RNA, effect that is already evident after a short time exposure.

\section{Effect of in vivo cisplatin-treatment on mitochondrial RNA metabolism}

In order to evaluate the in vivo relevance of the effects observed in vitro, we treated rats with cisplatin. The drug was injected intraperitoneally once at doses of either 10 or $20 \mathrm{mg}$ per kg of body weight. For each dose, the animals were sacrificed at 5, 24 or 48 hours after the administration (see Materials and Methods).

Liver mitochondria were isolated from animals treated in vivo with cisplatin and incubated in organello for 1 hour with $\left[\alpha^{32} \mathrm{P}\right]$ UTP. After incubation, mitochondrial 
nucleic acids were isolated and examined by electrophoresis. In vivo treatment with cisplatin caused various effects on mtRNA synthesis by isolated mitochondria depending on the dose and the time after the treatment (Fig. 3A and 3B). Thus, 10 $\mathrm{mg} / \mathrm{kg}$ cisplatin increased in organello RNA synthesis rate, whereas in vivo treatment with $20 \mathrm{mg} / \mathrm{kg}$ cisplatin slightly decreased it. These effects were already evident after 5 hours of cisplatin adeministration, raising to a maximum after 24 hours and returning to control levels after 48 hours (Fig. 3D, upper panel).

The effect of in vivo cisplatin treatment on mtRNA steady state levels was next examined. An increase on mitochondrial ribosomal RNA steady state level was found for both doses assayed (Fig. 3C). The change was moderate for the $20 \mathrm{mg} / \mathrm{kg}$ dose, but it reached a 3-fold increase for the $10 \mathrm{mg} / \mathrm{kg}$ dose. This effect was already evident after 5 hours of cisplatin administration, reaching a maximum after 24 hours and returning to control levels after 48 hours (Fig. 3D, lower panel).

\section{Effect of in vitro addition of cisplatin on mtRNA metabolism in mitochondria isolated from in vivo cisplatin-treated animals}

The addition of cisplatin to the incubation medium was found to directly inhibit mitochondrial RNA synthesis in organello, but the in vivo treatment of the animals with the drug increased mitochondrial transcription. In an attempt to clarify what is the effect of cisplatin on mitochondrial DNA metabolism and on mitochondrial activity, organelles from animals treated in vivo with $10 \mathrm{mg} / \mathrm{kg}$ cisplatin for $24 \mathrm{~h}$ were incubated with doses of cisplatin varying from 0 to $1.3 \mathrm{mM}$ for 1 hour. As expected, in organello RNA synthesis was inhibited by cisplatin both in mitochondria isolated from in vivo treated and non-treated animals, but surprisingly, this inhibition was less pronounced on the mitochondria isolated from in vivo cisplatin-treated animals (Fig. 4A, upper panel). In vitro addition of cisplatin to the incubation medium decreased mtRNA steady state levels both in mitochondria isolated from control and from in vivo cisplatin-treated animals, but the decrease was far more dramatic in the former case (Fig. 4A, lower panel, and Fig. 4B).

The above results pointed out the existence of in vivo mechanisms that reduce the damage of cisplatin to mtRNA metabolism.

\section{Effect of in vivo cisplatin treatment on GSH concentration}

To test this hypothesis, GSH metabolism was analyzed. GSH concentration was measured in total liver homogenates and in mitochondrial preparations from controls and from animals treated in yivo with cisplatin with a $10 \mathrm{mg} / \mathrm{kg}$ dose 5,24 or 48 hours prior to sacrifice. As shown in Table 1, after 24 hours of in vivo cisplatin treatment, the GSH levels increased both in total homogenate as in the mitochondrial fraction. The increase was significant in both cases when a non-parametric test was applied (Mann Whitney test, $\mathrm{p}=0.0495$ and $\mathrm{p}=0.0495$, respectively). After 5 and 48 hours of in vivo cisplatin treatment the GSH levels were slightly higher in both total homogenate and mitochondrial fraction, but this increase was not significant in any case.

Mitochondria isolated from control and in vivo treated animals with $10 \mathrm{mg} / \mathrm{kg}$ cisplatin for $24 \mathrm{~h}$ were next treated with $0.2 \mathrm{mM}$ of $N$-ethylmaleimide (NEM) for 15 minutes at room temperature. NEM modifies thiols groups, rendering them incapable of binding cisplatin. The HPLC analyses showed that $>75 \%$ of mitochondrial GSH in control samples and $>70 \%$ of mitochondrial GSH in in vivo cisplatin-treated samples was modified by NEM (GSH concentration was $2.28 \pm 0,1$ and $2.71 \pm 0,5$ nmoles $/ \mathrm{mg}$ mitochondrial protein for control and cisplatin in vivo treated mitochondria after NEM treatment respectively). 
Next, the effect of mitochondrial GSH concentration on mitochondrial RNA synthesis in organello and mitochondrial RNA stability was analysed (Fig. 5). As described before (Fig 4A), in organello RNA synthesis was inhibited by the in vitro addition of cisplatin both to mitochondria isolated from in vivo treated or non-treated animals, being the inhibition higher on mitochondria isolated from in vivo cisplatin non-treated animals (Fig. 5A and 5B). Very interestingly, when equivalent samples of mitochondria were used but pre-incubated with NEM (+NEM), in organello RNA synthesis was completely abolished even in the absence of cisplatin. Moreover, mitochondrial depletion of GSH impaired mtRNA stability and reverted the protective effect on mtRNA stability induced by in vivo treatment with cisplatin (Fig. 5C and 5D).

\section{DISCUSSION}

The results presented in this report, together with previous studies, allow us to propose that cisplatin accumulates in the mitochondria, binds to mtDNA, and most likely also to mtRNA, inducing their physical modification. This modification would be responsible for the inhibition of mtDNA and mtRNA synthesis and the decrease of mtRNA stability. Since mtDNA encodes for polypeptides that are components of the mitochondrial respiratory chain complexes, cisplatin direct effect on mitochondrial DNA metabolism could be the cause of the long-term decline of the mitochondrial respiration activity and ATP synthesis.

We show here that cisplatin causes a decrease of the mitochondrial oxygen consumption in isolated mitochondria and an increase of mitochondrial uncoupling between oxygen consumption and ATP synthesis. This result is in good agreement with previous studies describing that cisplatin induces decline in mitochondrial respiratory activity in vivo [34] and inhibition of the mitochondrial respiratory chain complexes in vitro $[23,35]$. However, this inhibition was observed at doses and/or exposure times higher than those needed to inhibit mtDNA synthesis and expression. This would agree with recent studies showing that cisplatin caused little or no immediate effect on mitochondrial function in various cancer cell lines, tumor cells, and beef heart submitochondrial particles as measured by oxygen consumption [36] but caused a long term inhibition of mitochondrial oxygen consumption which could be an indirect effect of the drug on mitochondrial activity [20].

By contrast, mtDNA synthesis appeared to be greatly inhibited at low cisplatin concentrations. It is well known that cisplatin binds to mtDNA. In studies with human malignant melanoma cells, cisplatin binding to mtDNA was 50 fold greater than to chromosomal DNA [37]. Cisplatin is able to induce intra-strand and inter-strand adduct formation on mtDNA [38], and mtDNA crosslink has been described in animals treated in vivo [37] and in in vitro treated cancer cells [39]., However, little is known about the consequences of these lesions on mitochondrial activity. DNA adducts can interfere with DNA synthesis. We have shown that cisplatin caused an impairment of mtDNA when used as template for PCR amplification. It has previously been demonstrated that cisplatin-DNA adducts do block Taq-polymerase and PCR essays have been used to analyze the effects of cisplatin on genomic DNA as well as on mitochondrial DNA [40]. Therefore, the formation of DNA adducts seems to be the more plausible explanation for the strong inhibition of mtDNA replication induced by cisplatin.

DNA adducts can interfere with DNA expression as well. We have shown that cisplatin directly inhibits mitochondrial DNA expression. Previous reports revealed that cisplatin-DNA adducts block elongation during in vitro RNA synthesis by procariotic and eucariotic RNA polymerases [41, 42]. Additionally, a 2 to 3-fold decrease in transcriptional activity was observed when platinum-modified reporter genes were 
transfected into human or hamster cells [43]. Cisplatin was also shown to substantially reduce transcription from the mouse mammary tumor virus promoter stably incorporated into mouse cells [44].

The decrease on mtRNAs steady-state levels was an interesting and unexpected observation. To our knowledge, such an effect had never been described before in cisplatin treatments. The decrease on mtRNAs newly synthesized by isolated mitochondria could have been due either to modifications in mtDNA transcriptional activity or to alterations of the mtRNA stability. We must stress that cisplatin induced both inhibition of mtRNA synthesis and decreased mtRNA stability, being both effects independent. One explanation would be that cisplatin interacts directly with mitochondrial RNAs and cause their structural modification inducing their earlier degradation. In any case, this hypothesis requires further investigation.

Unexpectedly in vivo treatment with cisplatin $(10 \mathrm{mg} / \mathrm{kg})$ promoted an increase of mtRNA synthesis in organello. Similarly, the stability of mtRNAs was increased in mitochondria isolated from animals treated in vivo with the drug. These results were apparently contradictory with the results we found in mitochondria incubated in vitro in presence of the drug. A scenario that conciliates both the in vitro and the in vivo results can be envisioned. After the in vivo treatment of the animals with cisplatin, the drug inhibits directly mtDNA synthesis and expression and decreases mtRNA stability. As a consequence, mitochondrial respiration is impaired and the cellular ATP levels are decreased. The cell reacts triggering compensatory mechanisms to maintain cellular ATP levels. Those would be the induction of genes involved in: (i) mitochondrial biogenesis, (ii) repair of mtDNA damage, (iii) cellular protection mechanisms such as decreased cellular uptake, (iv) increased cellular efflux of cisplatin, or (v) inactivation of the drug by sulfhydryl groups. These in vivo putative compensatory/defense mechanisms could be maintained, at least in part, in the mitochondria after their isolation and would explain the resistance to a direct alteration of mtDNA metabolism by cisplatin in mitochondria isolated from in vivo treated-animals.

In support of increased mitochondrial biogenesis, it has been reported that in vivo cisplatin treatment caused an elevation of mtDNA levels in rat liver [45]. The transcript level of mitochondrial 12S rRNA was increased by cisplatin treatment in two different cultured cell lines [46]. Cisplatin may increase mitochondrial transcription by altering activities of nuclear-encoded transcription factors in response to mtDNA damage, oxidative stress or other metabolic signals. It has been shown in cell culture that incubation with cisplatin resulted in up-regulation of Tfam, a mitochondrial transcription factor [47], which could explain the increase in mtRNA synthesis. However, the finding that mitochondria isolated from animals treated in vivo with the drug are more refractory, compared to control mitochondria, to the inhibition of transcription, reinforces the idea that a protection mechanism is induced by cisplatin in vivo treatment.

In this respect, we analyzed the levels of glutathion (GSH) as a potential protective pathway. GSH is critical in maintaining the protein sulphydryl groups in a reduced state and in the protection against oxidative stress through detoxification of reactive oxygen species [48]. Glutathion can similarly detoxify many exogenous toxins, including cisplatin, through the formation of glutathion adducts [49]. Pt ions entering the cell may preferentially bind to GSH and metallothionein, both present in millimolar concentrations in the cytoplasm. Formation of these complexes limits the amount of drug available for DNA binding and a positive correlation between GSH levels and resistance to cisplatin has been reported [11]. 
We found that in vivo treatment with cisplatin $(10 \mathrm{mg} / \mathrm{kg})$ induced an increase in the cytoplasmic and mitochondrial GSH concentration as it had been described in previous studies [11]. Modification of mitochondrial GSH with N-ethylmaleimide, NEM, caused a dramatic impairment of mitochondrial RNA synthesis in organello. The influence of sulphydryl groups on nuclear DNA platination by cisplatin have been demonstrated by an 8-fold increase in the amount of Pt-DNA adducts when cellular thiols were blocked by NEM [50]. A similar effect could work for mitochondria incubated in vitro with NEM. Mitochondrial GSH depletion may leave mtDNA unprotected for cisplatin damage.

It should be noted that all the in vivo effects we have described here were observed when we used the $10 \mathrm{mg} / \mathrm{kg}$ dose. Treatment of the animals with a higher dose, $20 \mathrm{mg} / \mathrm{kg}$, did not increase mtRNA synthesis nor stability. It is possible that the raising of the cisplatin dose, overwhelmed the compensatory mechanisms and the cells were no longer able to overcome the toxicity. The fact that the animals treated with 40 $\mathrm{mg} / \mathrm{kg}$ dose died before they were sacrificed may show a strong alteration of cell viability.

The in vitro and in vivo cisplatin concentrations used in our studies are clinically relevant $[35,37,51]$. Cisplatin-induced nephrotoxicity and neurotoxicity are the most severe and dose-limiting side effects for the therapeutic use of cisplatin, but dosedependent cisplatin-induced hepatotoxicity can alter the clinical situation in patients. It is known that cisplatin uptake by human liver is significant [52]. Hepatotoxicity was reported in studies where similar doses of cisplatin to those used in our study were administrated to rats $[52,53]$ and to humans [54].

In summary, the results presented in this report are the first biochemical evidence of a direct effect of cisplatin on mtDNA metabolism. These results together with the evidence of the protective effect exerted by GSH are fundamental for a better understanding of the cisplatin mechanism of action on tumor cells and of its toxic side effects on non-tumor cells.

\section{REFERENCES}

1 Rosencweig, M., Van Hoff, D. D., Slavik, M. and Muggia, R. M. (1977) Cisdiamminedichloroplatinum (II). A new anticancer drug. Ann. Intern. Med. 8, 803-812

2 Vokes, E. E., Weichselbaum, R. R., Mick, R., McEvilly, J. M., Haraf, D. J. and Panje, W. R. (1992) Favorable long-term survival following induction chemotherapy with cisplatin, fluorouracil, and leucovorin and concomitant chemoradiotherapy for locally advanced head and neck cancer. J. Natl. Cancer. Inst. 84, 877-882

3 Von Hoff, D. D., Schilsky, R. and Reichert, C. M. (1979) Toxic effects of cisdiamminedichloroplatinum (II) in man. Cancer Treat. Rep. 63, 1527-1531

4 Kartalou, M. and Essigmann, J. M. (2001) Mechanisms of resistance to cisplatin. Mutat. Res. 478, 23-43

5 Lindauer, E. and Holler, E. (1996) Cellular distribution and cellular reactivity of platinum (II) complexes. Biochem. Pharmacol. 52, 7-14

6 Zamble, D. B. and Lippard, S. J. (1999) The response of cellular proteins to cisplatin-damaged DNA. In Cisplatin: Chemistry and Biochemistry of a Leading Anticancer Drug. (Lippert, B., Ed.). Weinheim, Wiley-VCH, Zurich, 73-110 
7 Eastman, A. (1999) The mechanism of action of cisplatin: from adducts to apoptosis. In Cisplatin: Chemistry and Biochemistry of a Leading Anticancer Drug. (Lippert, B., Ed.). Weinheim, Wiley-VCH, Zurich, 111-134

8 Rich, T., Allen, R. L. and Wyllie, A. H. (2000) Defying death after DNA damage. Nature 407, 777-783

9 Dabholkar, M., Vionnet, J., Bostick-Bruton, F., Yu, J. J. and Reed, E. (1994) Messenger RNA levels of XPAC and ERCC1 in ovarian cancer tissue correlate with response to platinum-based chemotherapy. J. Clin. Invest. 94, 703-708

10 Fink, D., Zheng, H., Nebel, S., Norris, P. S., Aebi, S., Lin, T. P., Nehme, A., Christen, R. D., Haas, M., MacLeod, C. L. and Howell, S. B. (1997) In vitro and in vivo resistance to cisplatin in cells that have lost DNA mismatch repair. Cancer Res. 57, 1841-1845

11 Godwin, A. K., Meister, A., O'Dwyer, P. J., Huang, C. S., Hamilton, T. C. and Anderson, M. E. (1992) High resistance to cisplatin in human ovarian cancer cell lines is associated with marked increase of glutathione synthesis. Proc. Natl. Acad. Sci. U S A. 89, 3070-3074

12 Eastman, A. (1987) Cross-linking of glutathione to DNA by cancer chemotherapeutic platinum coordination complexes. Chem. Biol. Interact. 61, 241-248

13 Ishikawa, T. and Ali-Osman, F. (1993) Glutathione-associated cisdiamminedichloroplatinum (II) metabolism and ATP-dependent efflux from leukemia cells. Molecular characterization of glutathione-platinum complex and its biological significance. J. Biol. Chem. 268, 20116-20125

14 Strandberg, M. C., Bresnick, E. and Eastman, A. (1982) The significance of DNA cross-linking to cis-diamminedichloroplatinum (II)-induced cytotoxicity in sensitive and resistant lines of murine leukemia L1210 cells. Chem. Biol. Interact. 39, 169-180

15 Hengartner, M. O. (2000) The biochemistry of apoptosis. Nature 407, 770-6

16 Lemasters, J. J., Qian, T., Bradham, C. A., Brenner, D. A., Cascio, W. E., Trost, L. C., Nishimura, Y., Nieminen, A. L. and Herman, B. (1999) Mitochondrial dysfunction in the pathogenesis of necrotic and apoptotic cell death. J. Bioenerg. Biomembr. 31, 305-319

17 Szewczyk, A. and Wojtczak, L. (2002) Mitochondria as a pharmacological target. Pharmacol. Rev. 54, 101-127

18 Sharma, R. P. and Edwards, I. R. (1983) Cis-platinum: subcellular distribution and binding to cytosolic ligands. Biochem. Pharmacol. 73, 61-74

19 Cullen, K. J., Yang, Z., Schumaker, L. and Guo, Z. (2007) Mitochondria as a critical target of the therapeutic agent cisplatin in head and neck cancer. $J$ Bioenerg Biomembr. 39, 43-50

20 Tacka, K. A., Dabrowiak, J. C., Goodisman, J., Penefsky, H. S. and Souid, A. K. (2004) Effects of Cisplatin on Mitochondrial Function in Jurkat Cells. Chem. Res. Toxicol. 17, 1102-1111

21 Harper, M. E., Antoniou, A., Villalobos-Menuey, E., Russo, A., Trauger, R., Vendemelio, M., George, A., Bartholomew, R., Carlo, D., Shaikh, A., Kupperman, J., Newell, E. W., Bespalov, I. A., Wallace, S. S., Liu, Y., Rogers, J. R., Gibbs, G. L., Leahy, J. L., Camley, R. E., Melamede, R. and Newell, M. K. (2002) Characterization of a novel metabolic strategy used by drug-resistant tumor cells. FASEB J. 16, 1550-1557 
22 Murata, T., Hibasami, H., Maekawa, S., Tagawa, T. and Nakashima, K. (1990) Preferential binding of cisplatin to mitochondrial DNA and suppression of ATP generation in human malignant melanoma cells. Biochem. Int. 20, 949-955

23 Kruidering, M., vandeWater, B., deHeer, E., Mulder, G. J. and Nagelkerke, J. F. (1997) Cisplatin-induced nephrotoxicity in porcine proximal tubular cells: Mitochondrial dysfunction by inhibition of complexes I to IV of the respiratory chain. J. Pharmacol. Exp. Ther. 280, 638-649

24 Fernandez-Silva, P., Enriquez J. A. and Montoya, J. (2003) Replication and transcription of mammalian mitochondrial DNA. Exp. Physiol. 88, 41-56

25 Singh, G. and Maniccia-Bozzo, E. (1990) Evidence of lack of mitochondrial DNA repair following cis-dichlorodiammineplatinum treatment. Cancer Chemother. Pharmacol. 27, 97-100

26 Olivero, O. A., Chang, P. K., Lopez-Larraza, D. M., Semino-Mora, M. C. and Poirier, M. C. (1997) Preferential formation and decreased removal of cisplatinDNA adducts in Chinese hamster ovary cell mitochondrial DNA as compared to nuclear DNA. Mutat. Res. 391, 79-86

27 Enriquez, J. A., Ramos, J., Perez-Martos, A., Lopez-Perez, M. J. and Montoya, J. (1994) Highly efficient DNA synthesis in isolated mitochondria from rat liver. Nucleic Acids Res. 22, 1861-1865

28 Rebrink, I., Kamzalov, S. and Sohal, R. S. (2003) Effects of age and caloric restriction on glutathione redox state in mice. Free Radical Biology and Medicine 35, 626-635

29 Bradford, M. M. (1976) A rapid and sensitive method for the quantitation of microgram quantities of protein utilizing the principle of protein-dye binding. Anal. Biochem. 72, 248-254

30 Pastore, A., Massoud, R., Corradino, M., Lo Russo, A., Fucci, G., Cortese, C. and Federici, G. (1998) Fully automated assay for total homocysteine, cysteine, cysteinglycine, glutathione, cysteamine, and 2-mercaptopropionylglicine in plasma and urine. Automation and Analytical Techniques 44, 825-832

31 Enriquez, J. A., Perez-Martos, A., Lopez-Perez, M. J. and Montoya, J. (1996) In organello RNA synthesis system from mammalian liver and brain. Methods in Enzymology 264, 50-57

32 Fernandez-Silva, P., Enriquez, J. A. and Montoya, J. (1992) A Simple Procedure for Recovering the Denaturing Effect of Methylmercury in Agarose Gel Electrophoresis. BioTechniques 12, 480-482

33 Govan, H. L., Valles-Ayoub, Y. and Braun, J. (1990) Fine-mapping of DNA damage and repair in specific genomic segments. Nucleic Acids Res. 18, 38233830

34 Gordon, J. A. and Gattone, V. H. (1986) Mitochondrial alterations in cisplatininduced acute renal failure. Am. J. Physiol. 250, 991-998

35 Kruidering, M., Vandewater, B., Deheer, E., Mulder, G. J. and Nagelkerke, J. F. (1996) The use of porcine proximal tubular cells for studying nephrotoxicity in vitro: The role of oxidative stress in cisplatin-induced cell death. ATLA-Altern. Lab. Anim. 24, 161-172

36 Souid, A. K., Tacka, K. A., Galvan, K. A., Penefsky, H. S. (2003) Immediate effects of anticancer drugs on mitochondrial oxygen consumption. Biochem Pharmacol. 66, 977-987

37 Giurgiovich, A. J., Diwan, B. A., Olivero, O. A., Anderson, L. M., Rice, J. M. and Poirier, M. C. (1997) Elevated mitochondrial cisplatin-DNA adduct levels in rat tissues after transplacental cisplatin exposure. Carcinogenesis 18, 93-96 
38 Ledoux, S. P., Wilson, G. L., Beecham, E. J., Stevnsner, T., Wassermann, K. and Bohr, V. A. (1992) Repair of mitochondrial DNA after various types of DNA damage in chinese hamster ovary cells. Carcinogenesis 13, 1967-1973

39 Kalinowski, D. P., Illenye, S. and Van Houten, B. (1992) Analysis of DNA damage and repair in murine leukemia L1210 cells using a quantitative polymerase chain reaction assay. Nucleic Acids Res. 20, 3485-3494

40 Daoud, S. S., Clements, M. K. and Small, C. L. (1995) Polymerase chain reaction analysis of cisplatin-induced mitochondrial DNA damage in human ovarian carcinoma cells. Anticancer Drug 6, 405-412

41 Corda, Y., Job, C., Anin, M. F., Leng, M. and Job, D. (1991) Transcription by eucaryotic and procaryotic RNA polymerases of DNA modified at a d(GG) or a $\mathrm{d}(\mathrm{AG})$ site by the antitumor drug cis-diamminedichloroplatinum (II). Biochemistry 30, 222-230

42 Corda, Y., Anin, M. F., Leng, M. and Job, D. (1992) RNA polymerases react differently at $\mathrm{d}(\mathrm{ApG})$ and $\mathrm{d}(\mathrm{GpG})$ adducts in DNA modified by cisdiamminedichloroplatinum (II). Biochemistry 31, 1904-1908

43 Mello, J. A., Lippard, S. J. and Essigmann, J. M. (1995) DNA adducts of cisdiamminedichloroplatinum (II) and its trans isomer inhibit RNA polymerase II differentially in vivo. Biochemistry 34, 14783-14791

44 Mymryk, J. (1995) Cisplatin inhibits chromatin remodeling, transcription factor binding, and transcription from the mouse mammary tumor virus promoter in vivo. Biochemistry 92, 2076-2080

45 Maniccia-Bozzo, E., Espiritu, M. B. and Singh, G. (1990) Differential effects of cisplatin on mouse hepatic and renal mitochondrial DNA. Mol. Cell. Biochem. 94, 83-88

46 Hsui-Chuan, Y., Chung-Yi, N., Hideyuki, J. M., Chia-Pei, L., Sz-Yun, C., JengShu, W. and Lai-Chu, S. (2003) Increase of lipid peroxidation by cisplatin in WI38 cells but not in SV40-transformed WI38 cells. J. Chem. Mol. Tox. 17, 3946

47 Yoshida, Y., Izumi, H., Ise, T., Uramoto, H., Torigoe, T., Ishiguchi, H., Murakami, T., Tanabe, M., Nakayama, Y., Itoh, H., Kasai, H. and Kohno, K. (2002) Human mitochondrial transcription factor A binds preferentially to oxidatively damaged DNA. Biochem. Biophys. Res. Commun. 295, 945-951

48 Anderson, M. E. (1998) Glutathione: an overview of biosynthesis and modulation. Chem. Biol. Interact. 24, 1-14

49 Davis, W. J., Ronai, Z. and Tew, K. D. (2001) Cellular thiols and reactive oxygen species in drug-induced apoptosis. J. Pharmacol. Exp. Ther. 296, 1-6

50 Sadowitz, P. D., Hubbard, B. A., Dabrowiak, J. C., Goodisman, J., Tacka, K. A., Aktas, M. K., Cunningham, M. J., Dubowy, R. L. and Souid, A. K. (2002) Kinetics of cisplatin binding to cellular DNA and modulations by thiol-blocking agents and thiol drugs. Drug. Metab. Dispos. 30, 183-190

51 Zhang, J. G. and Lindup, W. E. (1993) Role of mitochondria in cisplatininduced oxidative damage exhibited by rat renal cortical slices. Biochem. Pharmacol. 45, 2215-2222

52 Zicca, A., Cafaggi, S., Mariggio, M. A., Vannozzi, M. O., Ottone, M., Bocchini, V., Caviglioli, G. and Viale, M. (2002) Reduction of cisplatin hepatotoxicity by procainamide hydrochloride in rats. Eur. J. Pharmacol. 442, 265-272

53 Pratibha, R., Sameer, R., Rataboli, P. V., Bhiwgade, D. A. and Dhume, C. Y. (2006) Enzymatic studies of cisplatin induced oxidative stress in hepatic tissue of rats. Eur. J. Pharmacol. 532, 290-293 
54 Cersosimo, R. J. (1993) Hepatotoxicity associated with cisplatin chemotherapy. Ann. Pharmacother. 27, 438-441

\section{FOOTNOTES}

* We would like to thank Santiago Morales for his technical assistance. Our work was supported by the Spanish Ministry of Education (SAF2006-00428), the Health Institute Carlos III (REDEMETH-G03/054 and REDCIEN C03/06-Grupo RC-N34-3), EU EUMITOCOMBAT-LSHM-CT-2004-503116), DGA research group of Excellence grant (B55 to NG, APM, PFS and JAE) and DGA Consolidated research group grant (B33 MLP and JM).

${ }^{1}$ The abbreviations used are: mtDNA, mitochondrial DNA; H, mtDNA heavy strand; L, mtDNA light strand; $\mathrm{OH}$, heavy strand replication origin; IL, light strand transcription origin; ND1, ND2, ND3, ND4, ND4L, ND5 and ND6 are subunits 1 to 6 and 4L of the NADH Dehydrogenase; Cytb, Cytochrome b; COI, COII and COIII are Cytochrome c oxidase subunits 1 to 3; A6, ATP synthase F0 subunit 6; A8, ATP synthase F0 subunit 8; rRNA, ribosomal RNA; mRNA, messenger RNA; tRNA, transfer RNA; 12S and 16S are the mitochondrial rRNAs; pre-RNA is for the precursor of mitochondrial RNAs; 7S mRNA synthesized from the light strand; Pt, platinum; NER, nucleotide excision repair; PCR, polymerase chain reaction; RCR, respiratory control ratio; GSH, gluthatione; sodium borohydride $\left(\mathrm{NaBH}_{4}\right)$; monobromobimane $(\mathrm{mBBr})$; meta-phosphoric acid (MPA); $N$-ethylmaleimide (NEM). 


\section{FIGURE LEGENDS}

\section{Figure 1. -Influence of cisplatin on mitochondrial oxidative phosphorylation and mtDNA replication}

(A) Effect of cisplatin on mitochondrial oxidative phosphorylation. RCR and $\mathrm{P} / \mathrm{O}$ ratios in mitochondria isolated from rat liver and incubated at $37^{\circ} \mathrm{C}$ for 1,2 or 3 hours with different cisplatin concentrations: $0,0.17,0.35$ and $0.7 \mathrm{mM}$ cisplatin respectively. Data are from three different experiments and expressed as mean $\pm \mathrm{SD}$.

(B) Effect of cisplatin on mitochondrial DNA synthesis. Autoradiogram after electrophoresis through agarose slab gel of newly synthesized mtDNA by isolated rat liver mitochondria incubated in the presence of $0,0.007,0.035,0.07,0.35$ and $0.7 \mathrm{mM}$ cisplatin. Each lane shows mtDNA synthesized by an equivalent amount of mitochondria. TTP uptake: percent of radioactivity trapped by mitochondria but not incorporated into mtDNA.

(C) Left: PCR amplification of mtDNA isolated from rat liver mitochondria after incubation for 1 hour at $37^{\circ} \mathrm{C}$ with $0,0.17,0.35,0.7,1$ and $1.4 \mathrm{mM}$ cisplatin. $\mathrm{C}_{1}$ : mtDNA control sample were cisplatin $1.4 \mathrm{mM}$ was added just before PCR amplification. Right: PCR amplification of mtDNA isolated from rat liver mitochondria and then incubated in vitro for 1 hour with the indicated cisplatin concentration. $\mathrm{C}_{2}$ : mtDNA control sample where cisplatin $1.5 \mathrm{nM}$ was added just before PCR amplification.

Figure 2. - Effect of cisplatin on mitochondrial RNA synthesis and stability

(A) Autoradiogram after electrophoresis on methylmercury hydroxide-agarose gels of newly mtRNAs synthesized in organello by isolated rat liver mitochondria incubated in the presence of $0,0.17,0.35,0.7,1$ and $1.4 \mathrm{mM}$ cisplatin (left), and incubated without cisplatin (-) or with $0.17 \mathrm{mM}$ cisplatin $(+)$ during 1,2 or 3 hours (right). Each lane shows mtRNAs synthesized by equivalent amounts of mitochondria. UTP uptake: percent of radioactivity trapped by mitochondria but not incorporated into mtRNA.

(B) Ethidium bromide staining after electrophoresis on methylmercury hydroxideagarose gels of mtDNA and mtRNAs isolated from rat liver mitochondria incubated with $0,0.17,0.35,0.7,1$ and $1.4 \mathrm{mM}$ cisplatin (left), and without cisplatin (-) or with $0.17 \mathrm{mM}$ cisplatin $(+)$ during 1,2 or 3 hours (right). Each lane shows nucleic acids isolated from an equivalent amount of mitochondria.

Figure 3. - Effect of the in vivo cisplatin treatment on mitochondrial RNA synthesis and stability

(A and B) Autoradiograms after electrophoresis on methylmercury hydroxide-agarose gels of newly synthesized mtRNAs by rat liver mitochondria isolated from animals treated in vivo without C, or with cisplatin T, at doses of $10 \mathrm{mg} / \mathrm{kg}$ (A) or $20 \mathrm{mg} / \mathrm{kg}$ (B) for 5, 24 or 48 hours. Each lane shows mtRNAs synthesized by an equivalent amount of mitochondria.

(C) Ethidium bromide staining after electrophoresis on methylmercury hydroxideagarose gels of mtDNA and mtRNAs isolated from rat liver mitochondria of three different animals (1,2 and 3) treated in vivo without (Control) or with $10 \mathrm{mg} / \mathrm{kg}$ cisplatin for 24 hours (Treated). Each lane shows nucleic acids isolated from an equivalent amount of mitochondria. 
(D) Upper panel: densitometric quantification from the autoradiography of the radioactivity incorporated into total mtRNA synthesized by mitochondria isolated from animals treated in vivo with $10 \mathrm{mg} / \mathrm{kg}$ (closed circles) or $20 \mathrm{mg} / \mathrm{kg}$ cisplatin (open circles) for 5, 24 or 48 hours. The radioactivity incorporated on mtRNA was normalized by the amount of mtDNA in each sample. Lower panel: densitometric quantification from the ethidium bromide gels of 16S mitochondrial rRNA isolated from rat liver mitochondria from animals treated in vivo with $10 \mathrm{mg} / \mathrm{kg}$ (closed circles) or $20 \mathrm{mg} / \mathrm{kg}$ cisplatin (open circles) for 5, 24 or 48 hours. mtRNA amount has been normalized by mtDNA in each sample. Data represent \% synthesis above control (100) from three different experiments \pm SD.

Figure 4. - Effect of the in vitro addition of cisplatin on mitochondrial RNA synthesis and stability to mitochondria isolated from in vivo cisplatin-treated animals

(A) Upper panel: densitometric quantification from the autoradiography of the radioactivity incorporated into total mtRNA synthesized in organello by mitochondria isolated from control animals (open circles) and animals treated in vivo with $10 \mathrm{mg} / \mathrm{kg}$ 24 hours (closed circles) and then incubated with $0,0.4$ and $1.3 \mathrm{mM}$ cisplatin, and ratio between the amount of RNA synthesized by rat liver mitochondria isolated from animals treated in vivo without or with $10 \mathrm{mg} / \mathrm{kg}$ cisplatin for 24 hours (squares). The radioactivity incorporated on mtRNA has been normalized by the amount of mtDNA in each sample. Data represent \% synthesis above the control (100). Lower panel: densitometric quantification from the ethidium bromide stained gels of $16 \mathrm{~S}$ mitochondrial rRNA isolated from rat liver mitochondria from control animals (open circles) and animals treated in vivo with $10 \mathrm{mg} / \mathrm{kg}$ cisplatin for 24 hours (closed circles) and then incubated with $0,0.4$ and $1.3 \mathrm{mM}$ cisplatin, and ratio between the amount of in vivo $16 \mathrm{~S}$ mitochondrial ribosomal RNA isolated from rat liver mitochondria of animals treated in vivo without or with $10 \mathrm{mg} / \mathrm{kg}$ cisplatin for 24 hours (squares). Data represent $\%$ synthesis above the control (100).

(B) Ethidium bromide staining after electrophoresis on methylmercury hydroxideagarose gels of mtDNA and mtRNAs isolated from rat liver mitochondria of animals treated in vivo without (Control animal) or with $10 \mathrm{mg} / \mathrm{kg}$ cisplatin for 24 hours (Treated animal) and incubated in vitro with $0,0.4$ and $1.3 \mathrm{mM}$ cisplatin. Each line shows nucleic acids isolated from an equivalent amount of mitochondria.

Figure 5. - Effect of GSH on mitochondrial RNA synthesis and stability

(A and B) Autoradiograms after electrophoresis on methylmercury hydroxide-agarose gels of newly synthesized mtRNAs by rat liver mitochondria isolated from animals treated in vivo without (Control animal) or with $10 \mathrm{mg} / \mathrm{kg}$ for 24 hours (In vivo cisplatin-treated animal), incubated in vitro without (-NEM) or with NEM $0.2 \mathrm{mM}$ $(+\mathrm{NEM}) 15 \mathrm{~min}$ at room temperature and then incubated with $0,0.4$ and $1.3 \mathrm{mM}$ cisplatin 1 hour at $37^{\circ} \mathrm{C}$. Each lane shows mtRNAs synthesized by an equivalent amount of mitochondria.

(C and D) Ethidium bromide staining after electrophoresis on methylmercury hydroxide-agarose gels of mtDNA and mtRNAs isolated from rat liver mitochondria of animals treated in vivo without (Control animal) or with $10 \mathrm{mg} / \mathrm{kg}$ cisplatin for 24 hours (in vivo cisplatin-treated animal), and incubated in vitro without (-NEM) or with NEM $0.2 \mathrm{mM}(+\mathrm{NEM}) 15 \mathrm{~min}$ at room temperature and then incubated with $0,0.4$ and 1.3 $\mathrm{mM}$ cisplatin for 1 hour at $37^{\circ} \mathrm{C}$. Each lane shows nucleic acids isolated from an equivalent amount of mitochondria. 
Table 1. -GSH concentration in total homogenate and in the mitochondrial fraction

\begin{tabular}{|l|c|c|c|c|c|c|}
\hline & $\begin{array}{c}\text { Control } \\
\text { 5hours }\end{array}$ & $\begin{array}{c}\text { Cisplatin } \\
\text { 5hours }\end{array}$ & $\begin{array}{c}\text { Control } \\
\text { 24hours }\end{array}$ & $\begin{array}{c}\text { Cisplatin } \\
\text { 24hours }\end{array}$ & $\begin{array}{c}\text { Control } \\
\text { 48hours }\end{array}$ & $\begin{array}{c}\text { Cisplatin } \\
\text { 48hours }\end{array}$ \\
\hline $\begin{array}{l}\text { nmolGSH/ } \\
\text { mg protein }\end{array}$ & $25,40 \pm 1,2$ & $26,75 \pm 1,3$ & $25,50 \pm 0,5$ & $31,50 \pm 0,8^{*}$ & $24,50 \pm 1,5$ & $25,05 \pm 0,9$ \\
\hline $\begin{array}{l}\text { nmolGSH/mg } \\
\text { mitochondrial } \\
\text { protein }\end{array}$ & $10,50 \pm 0,7$ & $10,85 \pm 0,8$ & $10,75 \pm 0,6$ & $15,25 \pm 0,7^{*}$ & $10,25 \pm 0,5$ & $10,75 \pm 0,8$ \\
\hline & $\begin{array}{c}\text { Control } \\
\text { 5hours } \\
+ \text { NEM }\end{array}$ & $\begin{array}{c}\text { Cisplatin } \\
\text { 5hours } \\
\text { +NEM }\end{array}$ & $\begin{array}{c}\text { Control } \\
\mathbf{2 4 h o u r s} \\
+ \text { NEM }\end{array}$ & $\begin{array}{c}\text { Cisplatin } \\
\mathbf{2 4 h o u r s} \\
+ \text { NEM }\end{array}$ & $\begin{array}{c}\text { Control } \\
\mathbf{4 8 h o u r s} \\
+\mathbf{N E M}\end{array}$ & $\begin{array}{c}\text { Cisplatin } \\
\text { 48hours } \\
+ \text { NEM }\end{array}$ \\
\hline $\begin{array}{l}\text { nmolGSH/mg } \\
\text { mitochondrial } \\
\text { protein }\end{array}$ & $2,42 \pm 0,4$ & $3,36 \pm 0,5$ & $2,28 \pm 0,1$ & $2,71 \pm 0,5$ & $1,78 \pm 0,1$ & $2,53 \pm 0,4$ \\
\hline
\end{tabular}

Animals were treated in vivo without (Control) or with cisplatin $10 \mathrm{mg} / \mathrm{kg}$ for 5 , 24 or 48 hours. Liver was extracted from the animals and GSH levels were determined by HPLC from total homogenates or mitochondrial fractions and after treatment of mitochondria with $N$-ethylmaleimide for 15 min at RT (Data for 3 different experiments $\pm \mathrm{SD}$ ). "Significant differences respect to control $\mathrm{p}<0.05$. 


\section{B Biochemical Journal Immediate Publication. Published on 22 Apr 2008 as manuscript BJ20071615}
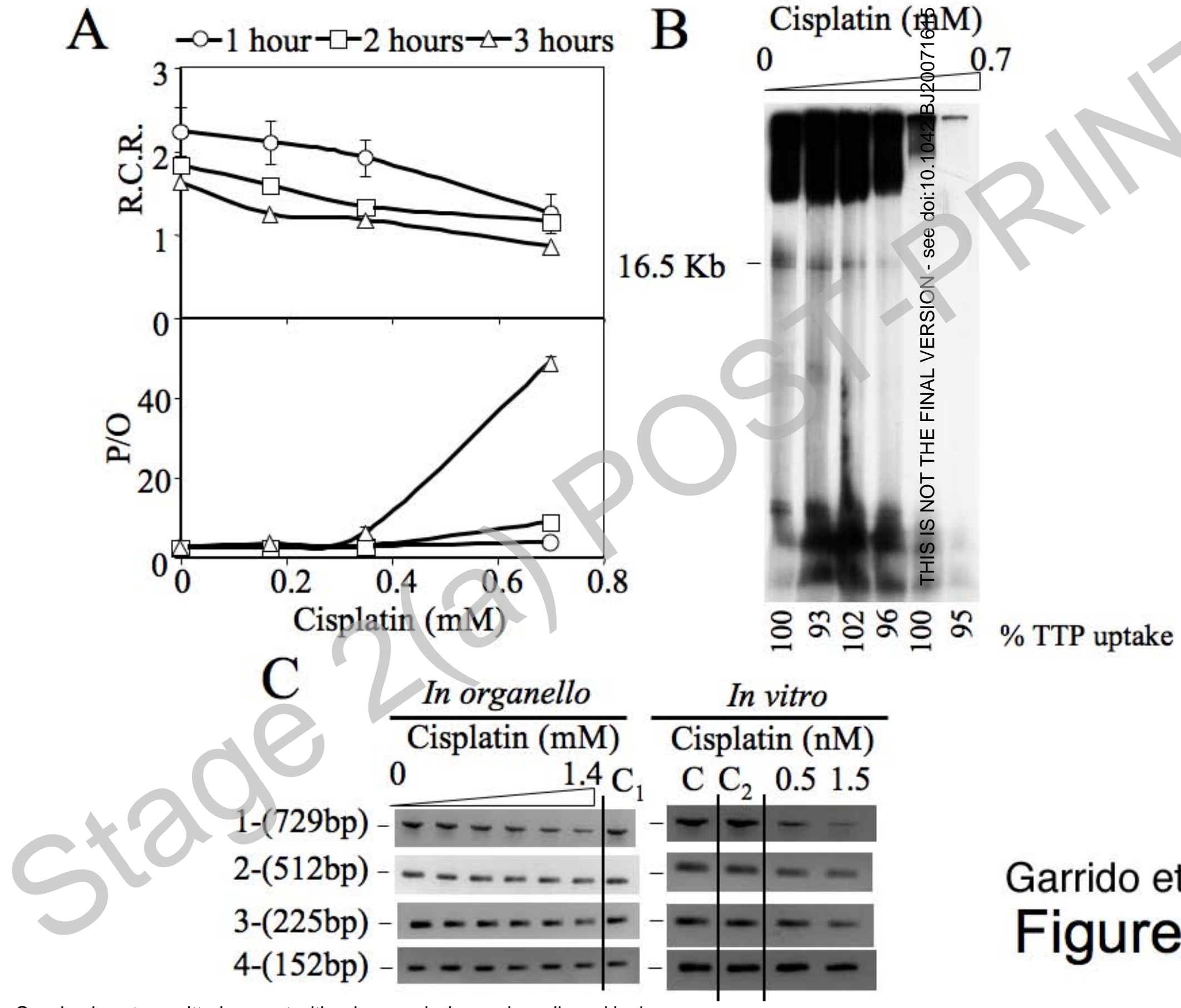

Garrido et al.
Figure 1

Licenced copy. Copying is not permitted, except with prior permission and as allowed by law.

(c) 2008 The Authors Journal compilation (c) 2008 Biochemical Society 
Biochemical Journal Immediate Publication. Published on 22 Apr 2008 as manuscript BJ20071615

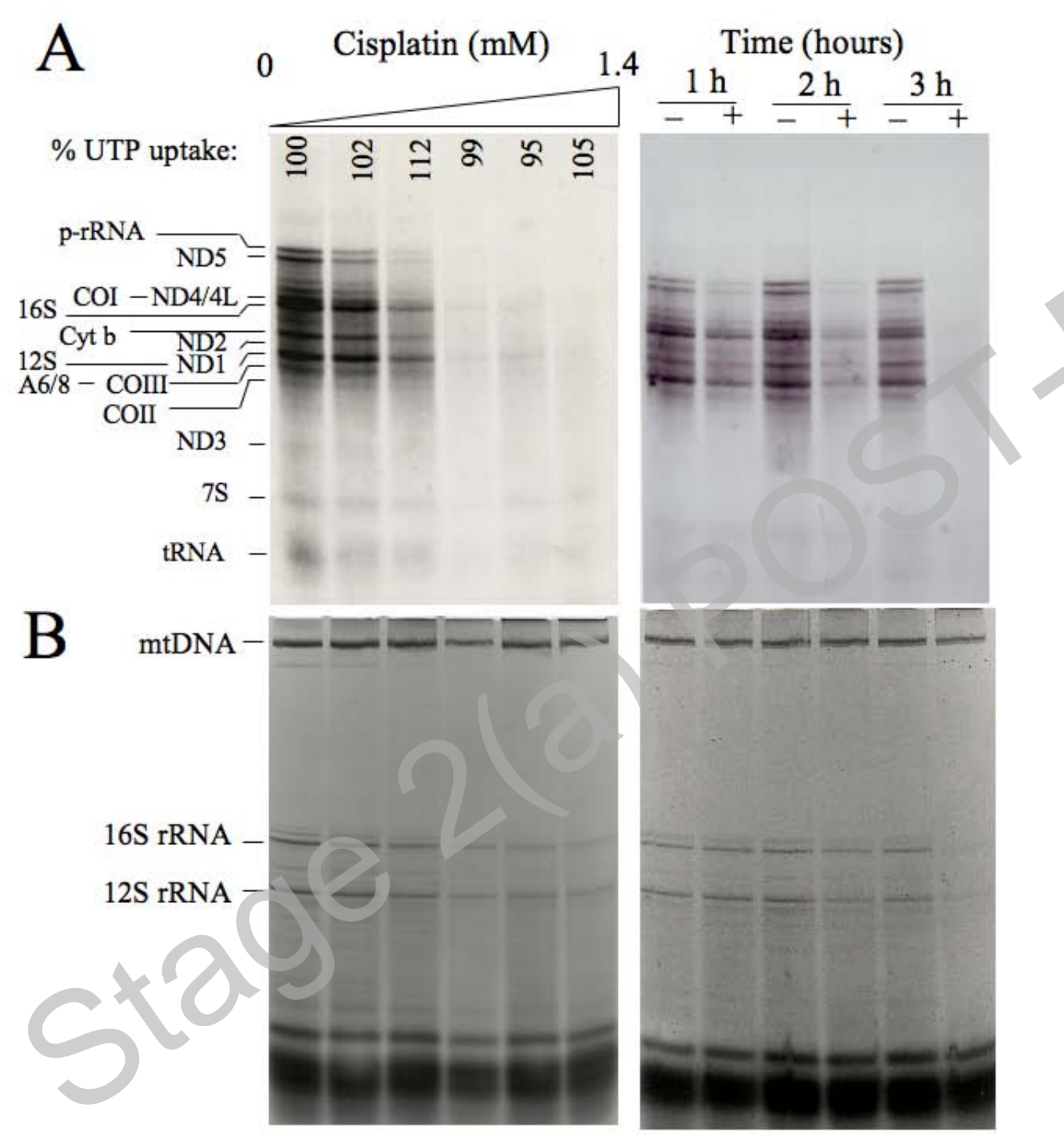

Garrido et al. Figure 2 
B Biochemical Journal Immediate Publication. Published on 22 Apr 2008 as manuscript BJ20071615

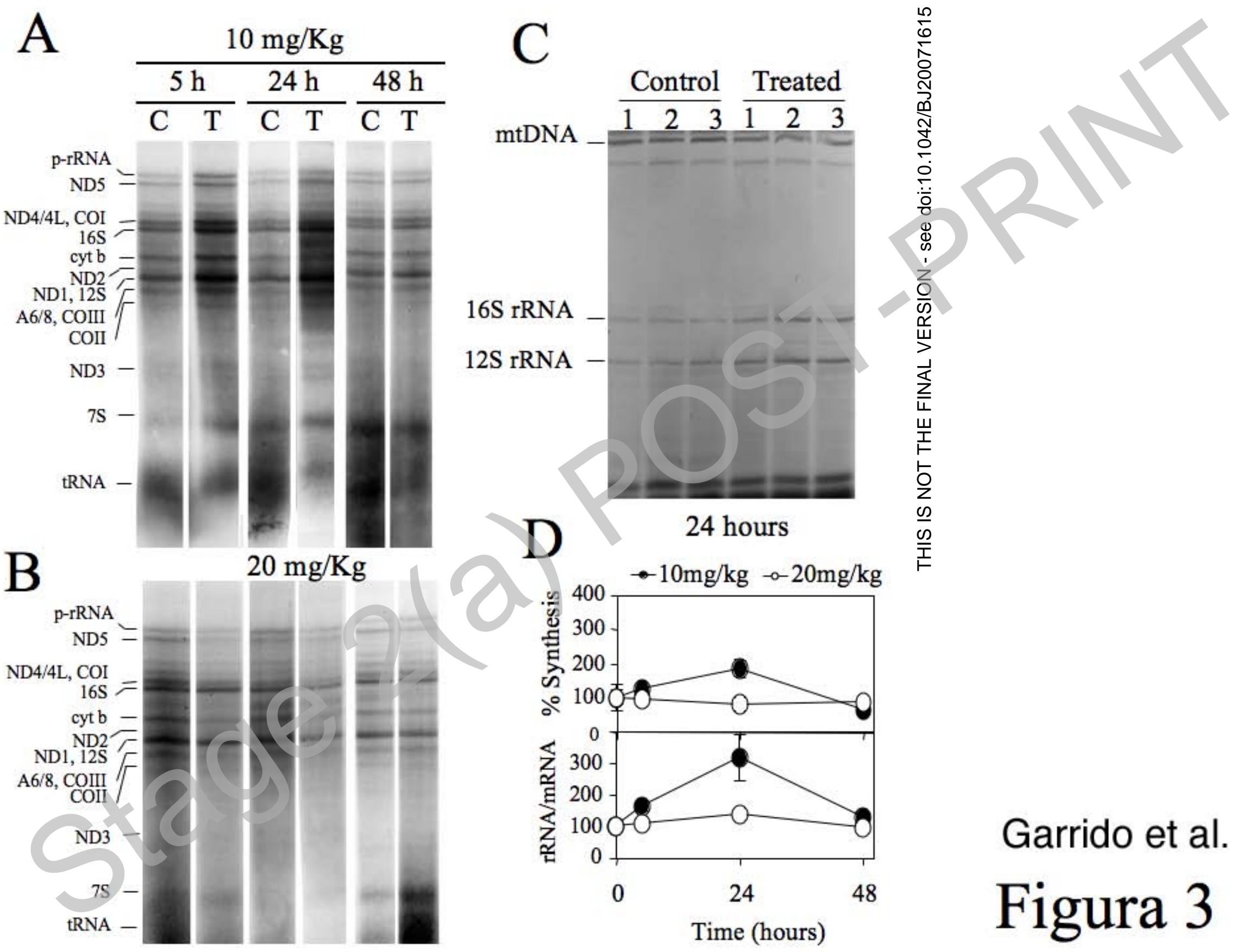

Licenced copy. Copying is not permitted, except with prior permission and as allowed by law. (c) 2008 The Authors Journal compilation (@ 2008 Biochemical Society 


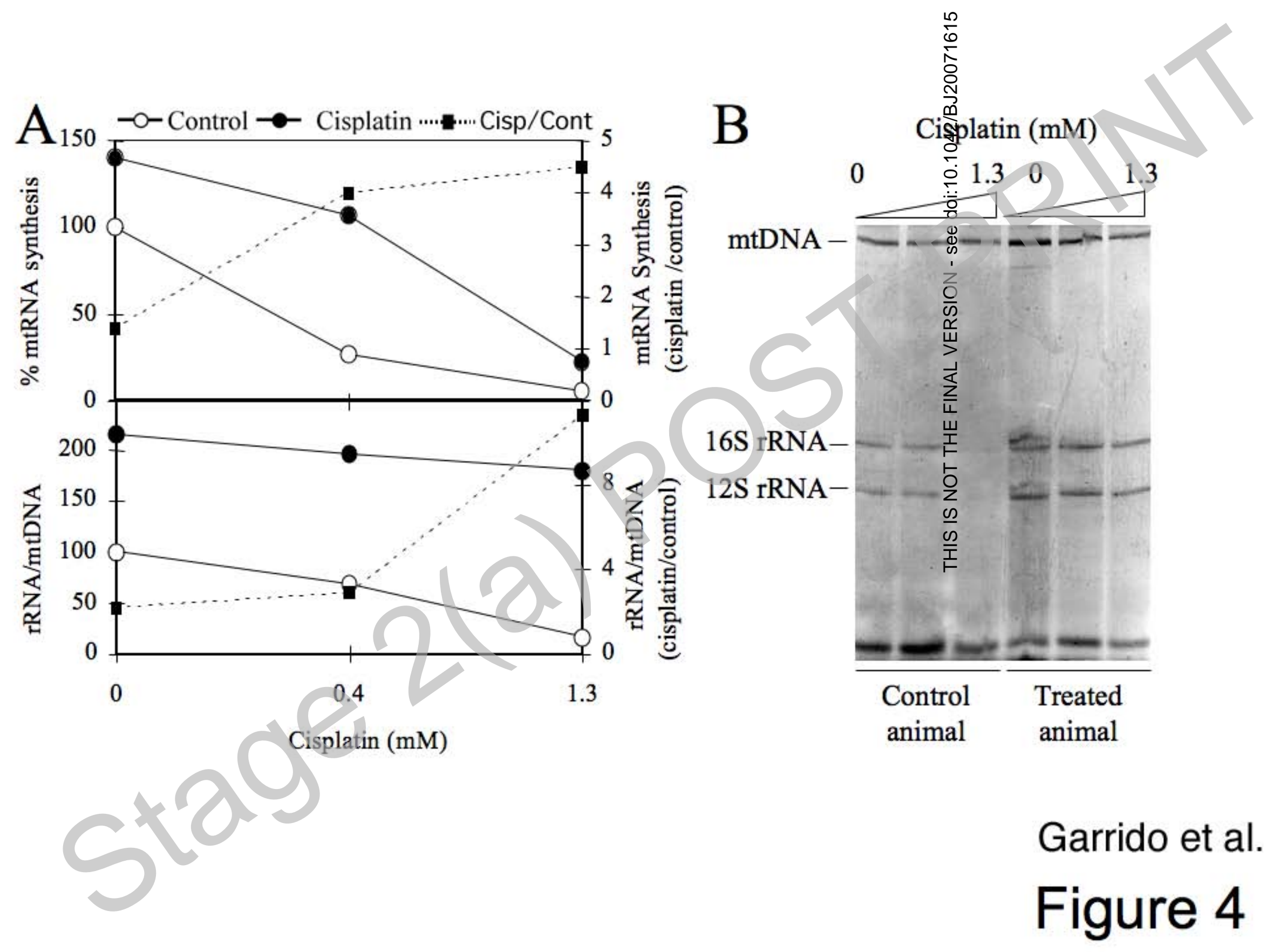




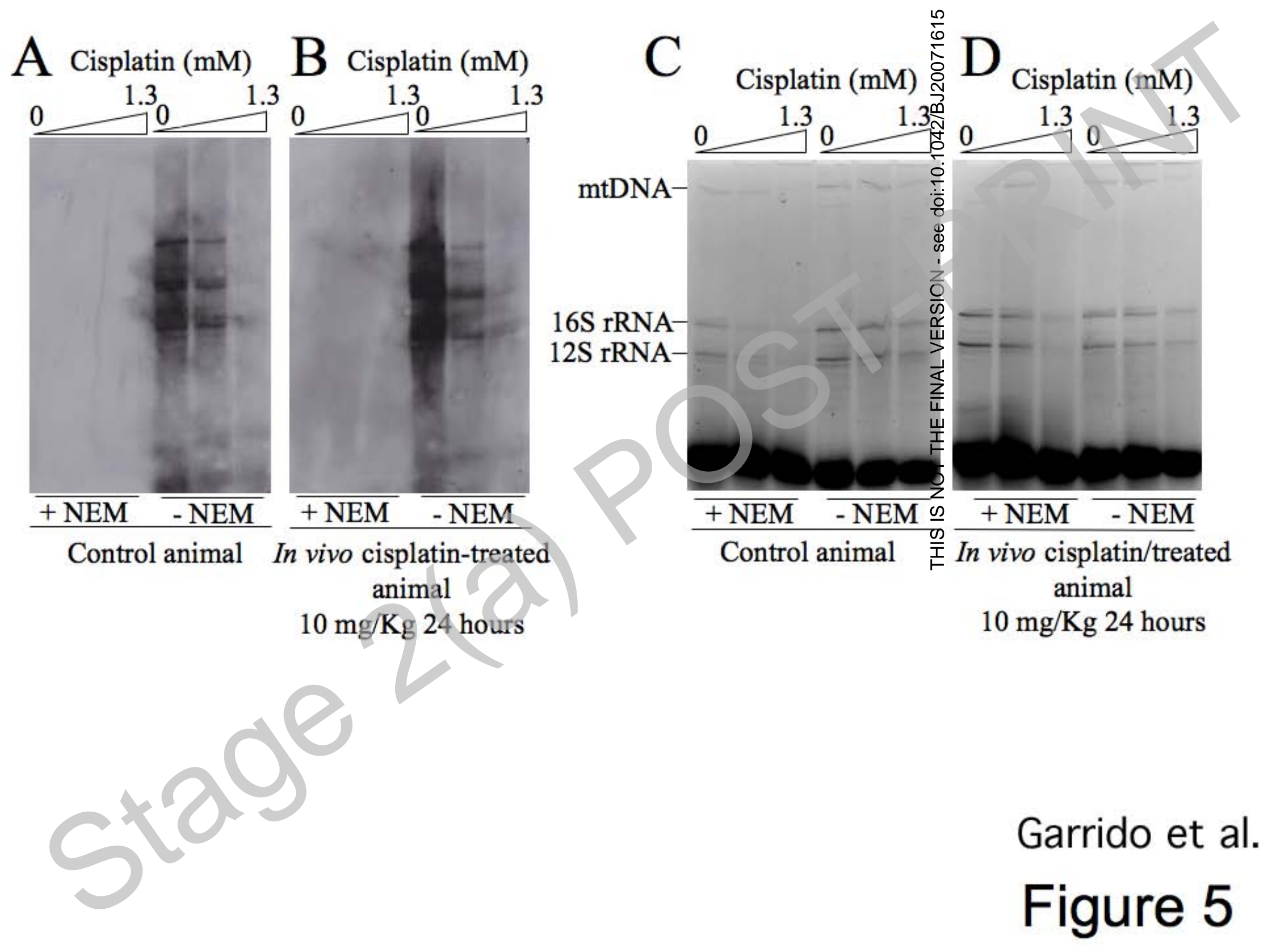

